Received 16 June 2019; accepted 20 November 2019.

Available online 30 Jan 2020

Toward Biophilic Egyptian Cities.

The Case of New Administrative Capital in Egypt.

Rania Nasreldin

Assistant Professor, Department of Architectural Engineering, Faculty of Engineering, Cairo University Giza, Egypt.

raniaibrahim@eng1.cu.edu.eg
Dalia Abdelfattah

Assistant Professor - visiting lecturer, Department of Architectural Engineering \& Environmental Design, Arab Academy for Science, Technology \& Maritime Transport, Cairo, Egypt. architect.dalia@gmail.com

\begin{abstract}
Human beings need contact with nature and the natural environment. Nature is not an optional, but absolutely essential quality of modern urban life. Biophilic city is a city full of nature in many different forms, it should consider nature at all levels, it is a place that learns from nature and emulates natural systems, incorporates natural forms and images into its buildings and cityscapes, and design and plans with nature, the experiential evidence of the truth of Biophilia, and social, psychological and other benefits from direct and indirect exposure to nature. It's important for emotional health and well-being, and human needs it for planetary health as well. It is not optional but essential. Capital Cairo is one of the newest Egyptian cities; it builds national spirit, provides for long-term sustainable growth, and aims to solve various issues faced by Egypt through a new city. This vision plan explores a set of strategies to guide growth over the next 40 to 50 years. Consequently, it must be resilient and sustainable enough to adjust to future changes and needs. This paper aims to sketch out guidelines needed to shift toward biophilic cities in the Egyptian new cities, based on Beatley's biophilic cities framework. Moreover, it explores how we can apply them to make the capital Cairo more biophilic, resilient, and sustainable.
\end{abstract}

Keywords: Biophilia, biophilic cities, Biophilic Urbanism, New Cairo capital city

\title{
Introduction
}

Nature in the biophilic city can be found in forms that are both large and small.The care for nature which is the core value in biophilic cities, extends even beyond its borders to take actions, steps and programs that help to defend over nature in other parts of the globe, A major task for modern cities is to become more compact and dense, but at the same time further closer connections to nature.

Biophilia literally means 'love for our living systems'. It is a term promoted by Edward O. Wilson in his book Biophilia (1984). Researchers show strong positive relationships between the presence of natural daylight, fresh air and greenery, with increase in users happiness and productivity ( Herschong,et al, 2002). Stephen Kellert along with others, especially Judith Heerwagen, Roger Ulrich, and Bill Browning, have done much researches on Biophilia. Their work has helped cultivate and stimulate the application of these ideas in architecture (Kellert, 2008)). Biophilic design has been organized for commercial and professional acceptance, especially by Terrapin Bright Green LLC (Browning et al ,2014) with 14 Patterns of Biophilic Design (Browning, Ryan, \& Clancy, 2014).

Biophilia extended to urban design scope, Tim Beatley has applied the idea to cities and tried to find what he calls a: 'daily dose of nature'(Beatley, 2011).Evidence 
suggests that the presence of green neighbourhoods has broader and more pervasive impacts on health than expected.( Maas et al,2009).

There is now a growing body of evidence of the positive mental and physical health benefits associated with greenery and green elements in living and work environments on architecture, urban and planning scale.(Beatley, 2017).

Cities like Singapore have done much to show how this is possible, and to imagine a dense city deep within nature and changed from "garden city" to "city in a garden. It is a good example of biophilic urbanism, where the expansion of green spaces and green buildings are being shown as regenerating the natural systems in the city and generating an urban ecosystem similar to the original structure, but with better biodiversity outcomes.(Newman, 2014).

Many cities in America have developed extensive incentives and subsidies for installation of green features, such as green rooftops. Others have established socalled Green Factor standards, mandating minimum green and landscaping elements for certain types of new development, and other cities setting the goal of a million new trees. (Beatley \& Newman, 2013)

This paper considers the adoption and position of biophilic urban design in Egypt, identifies biophilic patterns and principles found in extant and proposed examples of Egyptian urban design, with reference to appropriate international case study as Singapore.

Singapore is one of the cities that has a successful application on biophilic citystarted from 1993 its green strategic plan- in spite of it was already a build-up city not new one, and suffer from many urban problems, it is pushing the envelope in finding new and creative ways to include nature in the vertical realm .

Singapore also is considered as a developing country as Egypt, so lessons can be applied easily (not as the European Green Capital Award that shows so many countries how they became green capitals but these countries differ than the Egyptian context).

So this paper tries to explore lessons from this case study and how they can be applied to explore the relevance of those patterns and principles to the development of smart biophilic cities by applying Beatley 's framework on Cairo new capital.

\section{Biophilic City}

There is no definitive or single definition, no universal meaning, for what biophilic design and planning currently encompass or for what a biophilic city looks like. Biophilic cities should consider nature at all levels, from the microscopic to the bioregional and continental.

Wilson(1984), popularized the term Biophilia long ago to describe the extent to which humans are hardwired to need connection with nature and other forms of life. More specifically, he describes it this way: "Biophilia is the innately emotional affiliation of human beings to other living organisms. Innate means hereditary and hence part of ultimate human nature". (Wilson, 1984)

"A biophilic city is a city abundant with nature, a city that looks for opportunities to repair and restore and creatively insert nature wherever it can." It is a place that learns from nature and emulates natural systems, incorporates natural 
forms and images into its buildings and cityscapes, and designs and plans with nature(Beatley, 2011).

A biophilic city, moreover, is also a city in which residents are actively involved in experiencing nature-e.g., gardening, hiking, bird watching, sky-gazing, , among many other activities. Furthermore, citizens in biophilic cities have plentiful opportunities to be engaged in restoring and caring for the nature around them.(Beatley \& Newman, 2013)

Biophilic cities recognize the importance of creative strategies for bringing nature into the interior spaces of homes and offices. Interior green walls, natural ventilation, daylight, interior spaces, and interior forest atria are among the many ideas that can be embraced, and biophilic cities understand the health benefits of encouraging such features, not as substitutes, but as necessary supplements, to outside nature(Beatley, 2016)

It is not a thing or a place that could be periodically visited but a surrounding condition, an ideally ubiquitous context that delights, relaxes, soothes, replenishes, inspires, and uplifts urban lives. It is a nature full city. It puts nature at the core of its design and planning.

\section{Why Biophilic Cities?}

Biophilic cities have many positive impact not only on people health and wellbeing, but it also have an economic benefit, Biophilic cities are also profoundly resilient cities. Practically every step or action taken to increase nature in the city will help to make it more resilient. Biophilia is considered as the future of sustainable cities.(Beatley,T.,Newman,P,2013)

Many studies presented this impact of Biophilia on health and wellbeing in the build environment (Ryan, Browning, Clancy, Andrews, \& Kallianpurkar, 2014), it summarized each pattern and its impact on stress reduction, cognitive performance, emotion and mood enhancement and the human body.

There are many potential causal pathways by which nature can influence health, resilience and sustainability, biophilic Cities Causal Pathways is one of them. Figure 1 shows some of the most important direct and indirect impacts. Solid arrows are meant to indicate known causal effects between variables, though the dotted line indicates hypothesized or possible causal effects (Beatley, 2016).

Figure (1) Biophilic cities causal path model.

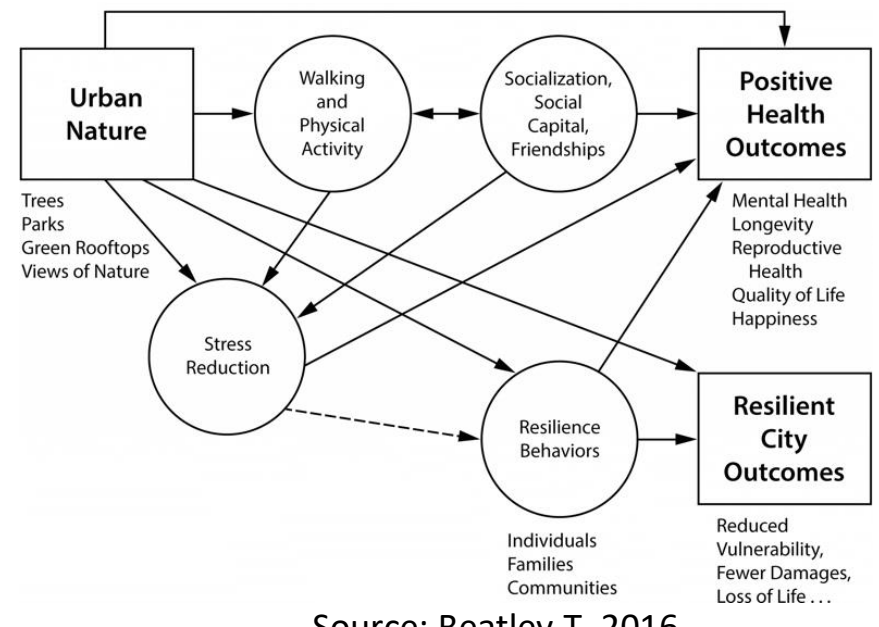

Source: Beatley,T.,2016 
There are few visions for future cities as compelling and as appealing as that of Biophilic Cities Indicators of a Biophilic City, Nature in all its forms will be the centre piece of a new global urbanism that leads to healthier people and healthier societies. (Beatley T. 2016).

\section{Elements and Attributes of Biophilic Design}

Biophilic elements have demonstrably real, measurable benefits for human performance metrics, such as productivity, emotional well-being, stress, learning, creativity, and healing.

Biophilic urbanism can and must take place at different scales, Cities and urban environments contain different ecological and green assets, from parks to trees to rivers and riparian habitats, and increasingly, efforts are being made to further enhance the green elements and features of these built up environments. Table 1 presents some examples of biophilic design interventions that are possible on different scales.

Table (1) Biophilic city design elements across scales.

\begin{tabular}{|c|c|}
\hline Scales & Biophilic design elements \\
\hline Building & $\begin{array}{l}\text { - Green rooftops } \\
\text { - Sky gardens and green atria. } \\
\text { - Rooftop garden. } \\
\text { - Green walls. } \\
\text { - Day lit interior spaces. }\end{array}$ \\
\hline Block & $\begin{array}{l}\text { - } \quad \text { Green courtyards. } \\
\text { - } \quad \text { Clustered housing around green areas. } \\
\text { - } \quad \text { Native species yards and spaces. }\end{array}$ \\
\hline Street & $\begin{array}{l}\text { - } \quad \text { Green streets. } \\
\text { - } \quad \text { Sidewalk gardens. } \\
\text { - } \quad \text { Low-impan trees. } \\
\text { - } \quad \text { Vegetated swales and skinny streets. } \\
\text { - Edible landscaping. } \\
\text { - } \quad \text { High degree of permeability. }\end{array}$ \\
\hline Neighbourhood & $\begin{array}{l}\text { - Stream day lighting, stream restoration. } \\
\text { - Urban forests. } \\
\text { - } \quad \text { Ecology parks. } \\
\text { - } \quad \text { Community gardens. } \\
\text { - } \quad \text { Neighborhood parks and pocket parks. } \\
\text { - Greening gray fields and brownfields. }\end{array}$ \\
\hline Community & $\begin{array}{l}\text { - Urban creeks and riparian areas. } \\
\text { - Urban ecological networks. } \\
\text { - Green schools. } \\
\text { - City tree canopy. } \\
\text { - } \quad \text { Community forest and community orchards. } \\
\text { - Greening utility corridors. }\end{array}$ \\
\hline Region & $\begin{array}{l}\text { - } \quad \text { River systems and floodplains. } \\
\text { - } \quad \text { Riparian systems. } \\
\text { - } \quad \text { Regional green space systems. } \\
\text { - } \text { Greening major transport corridors. }\end{array}$ \\
\hline
\end{tabular}

Source: Beatley,T.,Newman.P.,(2013) .Modified from (Girling, C.; Ronald, K.(2005) first appeared in( Beatley,2010]. 
Since this paper aims to sketch out the tools needed to shift toward biophilic cities in the Egyptian new cities especially on the capital Cairo. It makes the explicit argument that the actions and strategies can be taken in consideration to make the capital Cairo more biophilic on each level shown in table 1 to make it more resilient and sustainable.

\section{Biophilic Cities Examples}

Now a day, about $50 \%$ of the world population live in cities, and by 2050 , the percentage will increase to be about $70 \%$, so there is a need to study successful designed and planned cities that will accommodate with our economic and demographic needs.

The European cities are powerful sources of effective ideas and inspiring practice, but it differ in economic,cultural,urban context, and this make it's hard to learn lessons from these cities.( Beatley,T.2012).

Some European cities serve as a role model that inspire other green sustainable cities, Now a day, The green capital award is consider as a brand, a title and a prize, its award taken by 15 European cities based on its environmental record, as shown in table (2).

Table (2) European Green Capital award

\begin{tabular}{|c|c|}
\hline \multicolumn{2}{|l|}{ European Green Capital } \\
\hline - Criteria of evaluation & year /Capital award \\
\hline $\begin{array}{l}\text { - Climate Change: Mitigation } \\
\text { - Climate Change: Adaptation } \\
\text { - Sustainable Urban Mobility } \\
\text { - Sustainable Land Use } \\
\text { - Nature and Biodiversity } \\
\text { - Air Quality } \\
\text { - Noise } \\
\text { - Waste } \\
\text { - Water } \\
\text { - Green Growth and Eco-innovation } \\
\text { - Energy Performance } \\
\text { - Governance }\end{array}$ & $\begin{array}{ll}\text { - 2010: } & \text { Stockholm } \\
\text { - 2011: } & \text { Hamburg } \\
\text { - 2012: } & \text { Vitoria- } \\
\text { - } & \text { Gasteiz } \\
\text { - 2013: } & \text { Nantes } \\
\text { - 2014: } & \text { Copenhagen } \\
\text { - 2015: } & \text { Bjistol } \\
\text { - 2017: } & \text { Essubljana } \\
\text { - 2018: } & \text { Nijmegen } \\
\text { - 2019: } & \text { Oslo }\end{array}$ \\
\hline
\end{tabular}

Source: https://ec.europa.eu/environment/europeangreencapital/

In addition to these European cities that represent an important laboratory for a variety of ideas and strategies for biophilic green cities, there are some other American cities that can represent unique green cities strategies and lessons to learn.( Beatley,T.2012) as shown in table 3. 
Table (3) examples of biophilic cities in USA

\begin{tabular}{|c|c|c|c|}
\hline $\begin{array}{l}\text { Biophil } \\
\text { ic } \\
\text { cities }\end{array}$ & $\begin{array}{l}\text { MILWAUKEE, } \\
\text { WISCONSIN,USA }\end{array}$ & $\begin{array}{l}\text { PITTSBURGH, } \\
\text { PENNSYLVANIA,USA }\end{array}$ & WASHINGTON, DC \\
\hline Brief & $\begin{array}{l}\text { Milwaukee has made } \\
\text { considerable strides in } \\
\text { urban Sustainability, which } \\
\text { is now a priority issue for } \\
\text { the current mayor }\end{array}$ & $\begin{array}{l}\text { The city's main biophilic } \\
\text { endeavours have focused on } \\
\text { improving both air and } \\
\text { water quality, also } \\
\text { increasing residents' } \\
\text { awareness with the natural } \\
\text { world. City strategy focuses } \\
\text { on creating partnerships to } \\
\text { enhance the city's } \\
\text { biodiversity, increase tree } \\
\text { canopy, install green } \\
\text { infrastructure, daylight } \\
\text { streams, plan and work with } \\
\text { the Urban Sustainability } \\
\text { Directors Network to } \\
\text { develop a biodiversity } \\
\text { framework tool }\end{array}$ & $\begin{array}{l}\text { Washington DC is known for } \\
\text { its many parks and trees, as } \\
\text { well as its monuments. } \\
\text { Over the last decade, the City } \\
\text { has become known for its } \\
\text { progressive environmental } \\
\text { policies, especially in the areas } \\
\text { of energy and the built } \\
\text { environment. DC has one of } \\
\text { the largest numbers of } \\
\text { ENERGY STAR-rated and LEED- } \\
\text { certified buildings in the } \\
\text { country }\end{array}$ \\
\hline $\begin{array}{l}\text { Action } \\
\text { plan }\end{array}$ & $\begin{array}{l}\text { https://county.milwaukee. } \\
\text { gov/ImageLibrary/Groups/ } \\
\text { cntyParks/Planning/2015- } \\
\text { 2020StrategicPlan/2015- } \\
\text { 2020ExecutiveSummaryFin } \\
\text { al1.pdf }\end{array}$ & $\begin{array}{l}\text { https://pittsburghpa.gov/dc } \\
\text { p/sustainability-resilience }\end{array}$ & $\begin{array}{l}\text { http://www.sustainabledc.org } \\
/\end{array}$ \\
\hline $\begin{array}{l}\text { Biophil } \\
\text { ic city } \\
\text { networ } \\
k\end{array}$ & $\begin{array}{l}\text { https://www.biophiliccitie } \\
\text { s.org/milwaukee }\end{array}$ & $\begin{array}{l}\text { https://www.biophiliccities. } \\
\text { org/pittsburgh }\end{array}$ & $\begin{array}{l}\text { https://www.biophilic } \\
\text { cities.org/washington-dc }\end{array}$ \\
\hline
\end{tabular}

Source: https://www.biophiliccities.org/partner-cities

\section{Singapore case study "From Garden City to City in a Garden"}

This section outlines the characteristics of an emerging biophilic urbanism by detailing a case study of Singapore, which, over a number of years, has demonstrated how high density already built up city, limitation of resources and Land Scarcity does not have to mean reduced natural systems.

The biophilic urbanism works to improve natural systems in public spaces, between buildings and on the facades and rooftops of buildings. Singapore started in 1993 by exploring the first green plan, then "The Singapore Green Plan" was launched in 2002, both strategies aim to sift Singapore to green sustainable city, by applying these strategies on many levels as air ,water and land.(The singapore green plan 2012).

The Sustainable Singapore Blueprint was launched by the IMCSD in 2009, which sets out sustainable development goals to 2030 ,its vision is divided into 3 
main goals, A Liveable \& Endearing Home, A Vibrant \& Sustainable City and An Active \& Gracious Community(En, 2017).

The analysis of Singapore case study based on many studies as ,(Newman, 2010), (NParks, 2012)and (Newman, 2014) and based on the governmental reports of the ministry of building and construction authority as shown in table 6 .

Singapore's Biophilic urbanism works on many levels starting with building scale. It is, in fact, they use the existing structures to create new urban ecosystems between buildings and all over buildings which never considered possible before.

\section{1 criteria of success}

The importance of Singapore's biophilic urbanism is that it demonstrates the $p$ ossibility that dense cities may regenerate natural systems and create more natural urban systems, Moreover, t demonstrates that biophilic urbanism is not really difficult or expensive; actually, it can be achieved by developing country if they are inspired and motivated. Singapore considered as one of the sustainable and resilient cities (Towards a sustainable and resilient Singapore,2018).

Table (4) Green Spaces in Singapore

\begin{tabular}{c|c|c}
\hline year & $\mathbf{2 0 0 9}$ & $\mathbf{2 0 1 3}$ \\
\hline Amount of skyrise greenery(ha) & 10 & 61 \\
Amount of green space(ha) & 3602 & 4040 \\
Length of park connectors(km) & 113 & 216 \\
Amount of water bodies open for recreational activity(ha) & 650 & 959 \\
Length of waterways open for recreational activity $(\mathrm{km})$ & 72 & 93 \\
\hline
\end{tabular}

Source. Ministry of the Environment and Water Resources (2014, p. 12).

\section{The new administrative capital " wedian city"}

Wedian' plural for the Arabic word for 'Wady' which translates to "Valley", this project was named as such due to its consisting of 12 distinct valleys that will serve as hubs for different sectors.( UDC 5+,October 2017).

It is located at a distance approximately $45 \mathrm{~km}$ away from the centre of the old city, and lies on the outer peripheries of the Greater Cairo Region.

The proposal is bound on three of its sides by existing developments as well as high-speed highways. To the West of the new city is the existing and quickly expanding satellite city 'New Cairo' as well as the private and gated development of Madinaty. Existing highways connecting Cairo to the port cities of Suez and Ain el Sokhna then define the Northern and Southern edges of Wedian.

Based on a series of official announcements and documents released regarding the project the new Administrative capital is planned to cover a land area of approximately 146,000 Feddans for 15 million people. 


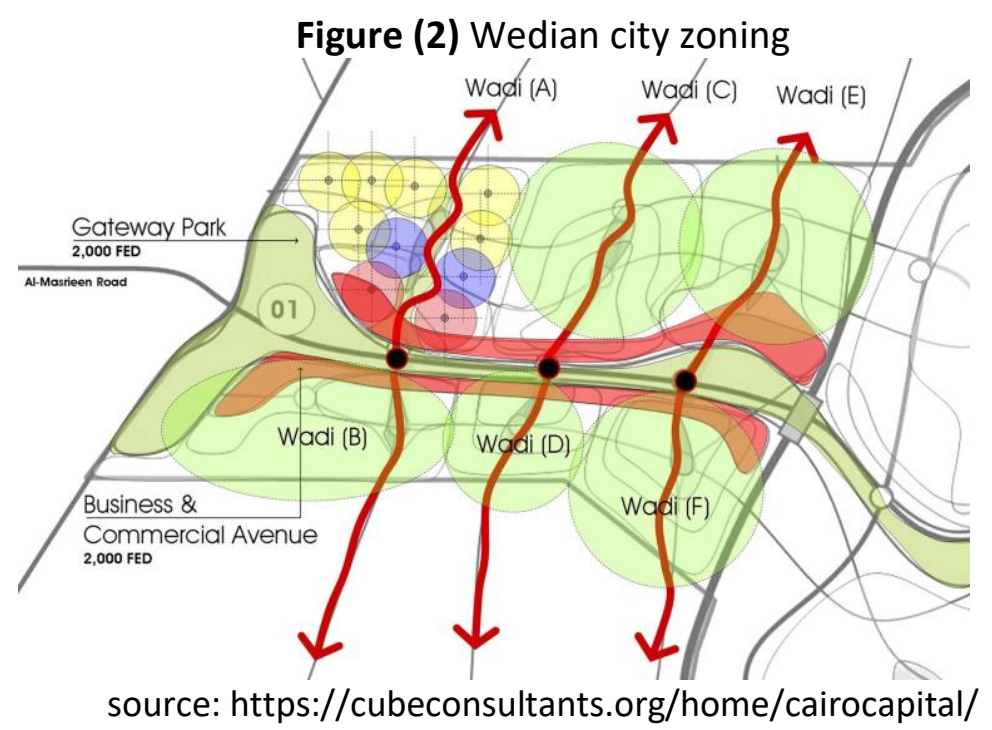

This new city will be the Egyptian Government's new administrative capital. It is a mega sized project that will include Egypt's largest public park spanning 2,000 Feddan sideways 35 kilometers of the city's spine.

\subsection{Design vision and mission}

The vision is: "Constructing a modern and current new Egyptian City that creates the base of Egypt's deeply rooted culture and presents to the world a worldly and human prototype to build a life with innovation." the vision is focused on best global practices in ecology, design and culture. Considering the issue of population density and land constraint, the city will be built with a variety of medium and high-density districts. (http://thecapitalcairo.com)

Its mission is "Integrated growth and development that spurs a good and socially just life, connected to services, environmentally friendly and sustainable growth that respects the characteristics of history and place". (According to Urban Development Construction UDC5+-).

This new Cairo capital city is a Smart City, and it will embrace an ethos of sustainability born from Egypt's tradition. The new capital will consider the sustainable technologies of today as well as be adaptable to future technologies, further enhancing its resource-efficiency. It calls for a new destination designed to embrace and adapt its natural desert setting

Figure(3) Wedian city Main concept
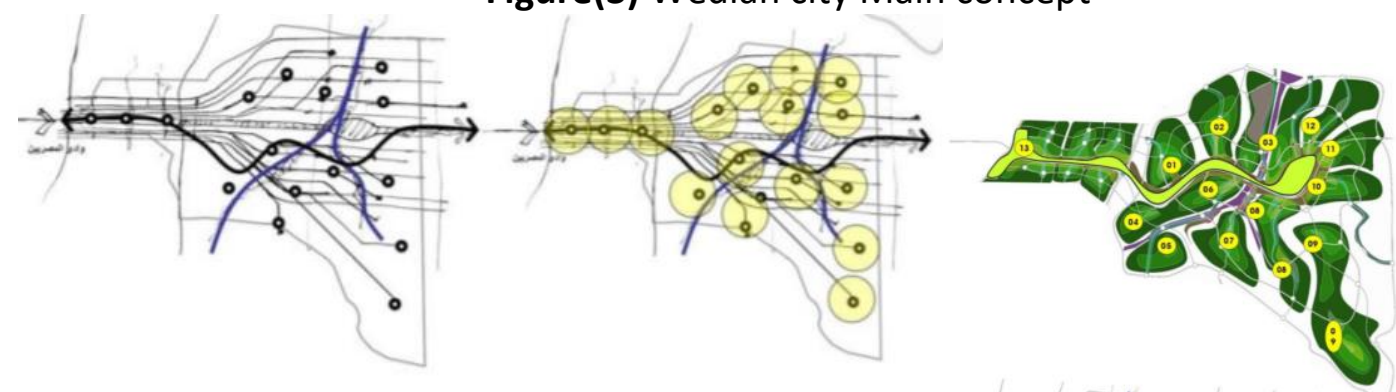

Source: Urban Development Consortium,UDC 5+

\subsection{The city design principles}

The city was designed based on 7 main principles as shown in table 5 . 
Table (5) New Cairo capital's design principles

\begin{tabular}{|c|c|}
\hline & $\begin{array}{l}\text { Green city } \\
15 \mathrm{~m} 2 \text { green open spaces for each person } \\
\text { The Cairo capital is designed to be a sustainable green city, a } \\
\text { community of residents, workers, and visitors who strive together } \\
\text { to balance ecological, economic, and social needs to ensure a safe, } \\
\text { clean and healthy environment for all members of society and for } \\
\text { generations to come. }\end{array}$ \\
\hline & $\begin{array}{l}\text { Sustainable city } \\
\quad 70 \% \text { of the buildings roofs covered by solar cells and greens } \\
\text { It is designed to be green, sustainable, welcoming to all the needs } \\
\text { and desires of the citizens. And it is allocated as an authenticity for } \\
\text { all Egyptians. }\end{array}$ \\
\hline & $\begin{array}{l}\text { Walk able city } \\
\text { The Cairo capital is designed to be a walkable city which } \\
\text { means that it stresses on the walkability concept as a } \\
\text { measurement of how friendly an area is to walking. }\end{array}$ \\
\hline Livable C & $\begin{array}{l}\text { Liveable city (city for life) } \\
\quad 30 \% \text { of total area for residential use ( } 1.5 \text { million residential } \\
\text { unit). walking and bicycling, where public spaces are beautiful, } \\
\text { well-designed, and well-maintained, and where housing is } \\
\text { relatively affordable. }\end{array}$ \\
\hline Connected & $\begin{array}{l}\text { Connected city } \\
\text { Different types of transportations }\end{array}$ \\
\hline & $\begin{array}{l}\text { Smart city } \\
70 \% \text { of the city contain and connected to the internet. } \\
\text { It has many utilities, services, and various transportations. }\end{array}$ \\
\hline Bussines city & $\begin{array}{l}\text { Business city } \\
\quad 30 \% \text { of the city serve business sector. It is designed to be } \\
\text { consistent, welcoming for all Egyptians, with different scales and } \\
\text { areas. }\end{array}$ \\
\hline
\end{tabular}

Source: https://cubeconsultants.org/home/cairocapital/

Although green city is one of the main principles of Cairo capital city planning, there are no any suggestions for how to make this city a green one or how to apply these principles.

\subsection{The capital Cairo's Master plan}

The master plan is to create a global city with smart infrastructure for Egypt's future, which will provide a multitude of economic opportunities and will offer a distinct quality of life.

Master plan land budget as shown in figure 4:

$30 \%$ residential area

$15 \%$ green and open spaces

$25 \%$ regional and business services

$10 \%$ services

$20 \%$ roads 
Figure (4) The capital Cairo's Master plan

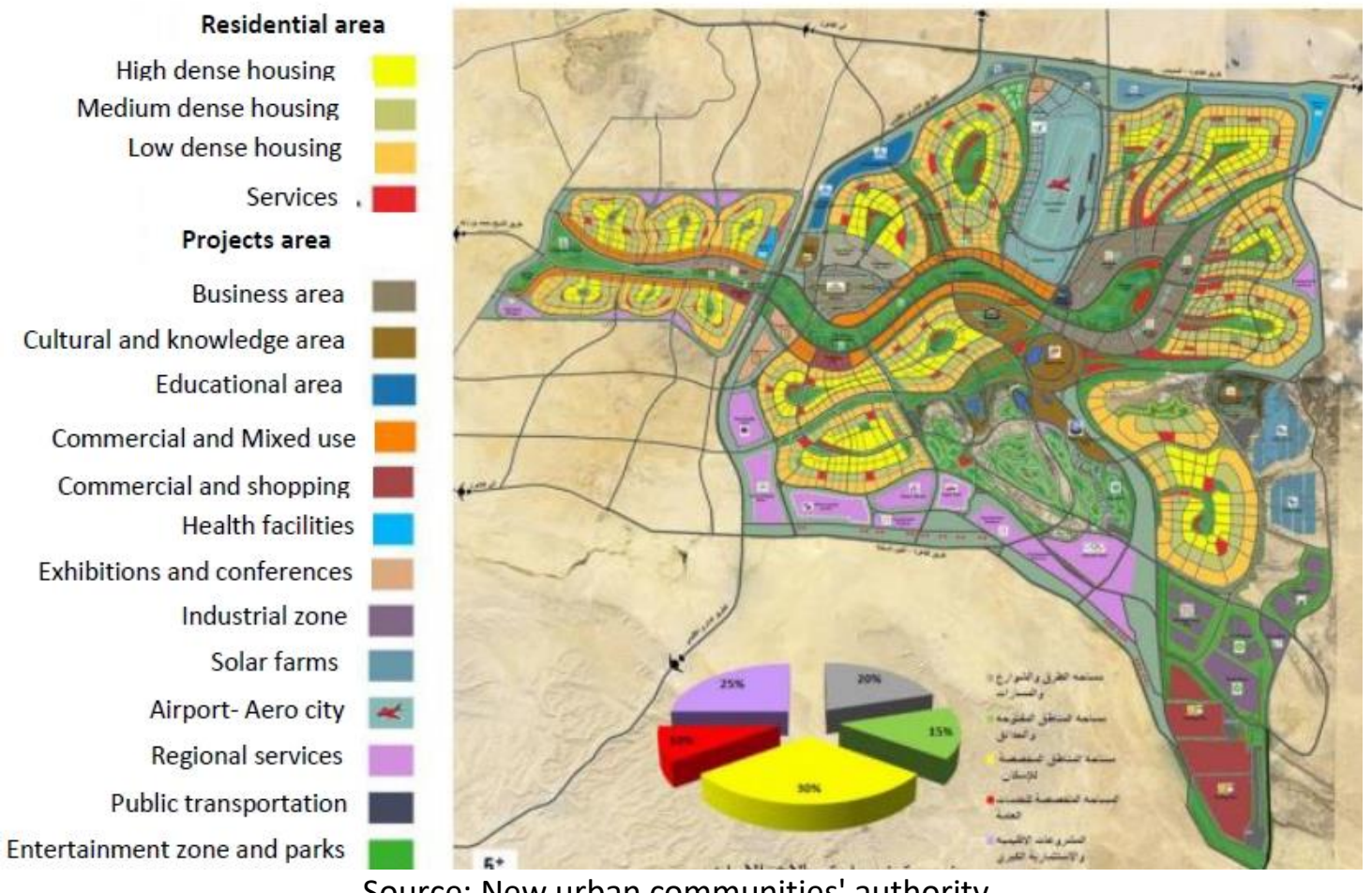

Source: New urban communities' authority

\subsection{Wedian city's $1^{\text {st }}$ stage}

This paper focuses and study the biophilic principles on the first stage of the-

new Cairo capital only with area of 40000 feddan as shown in figure 5, the research aims to apply biophilic city principles on the business park to insure sustainability and city resilience.

Figure (5) the capital Cairo's $1^{\text {st }}$ stage master plan.

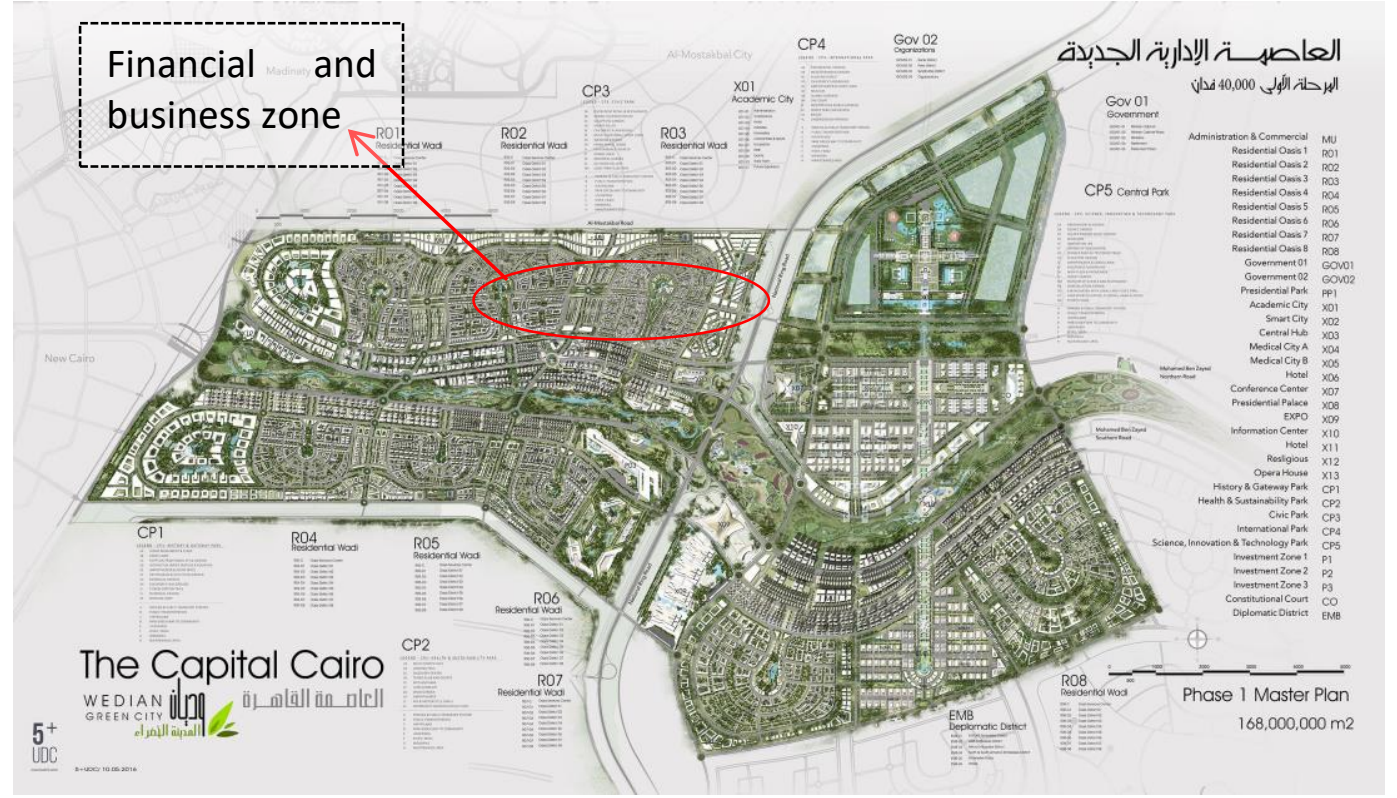

Source: Urban Development Consortium, UDC 5+ 


\subsection{Financial and business zone}

The total area 898.5 feddan, It is divided to 6 different zones as shown in figure 6 . It contains many land uses as shown in figure 6, such as mixed use area, residential, commercial, administrative area.

Figure (6) financial and business zone master plan.

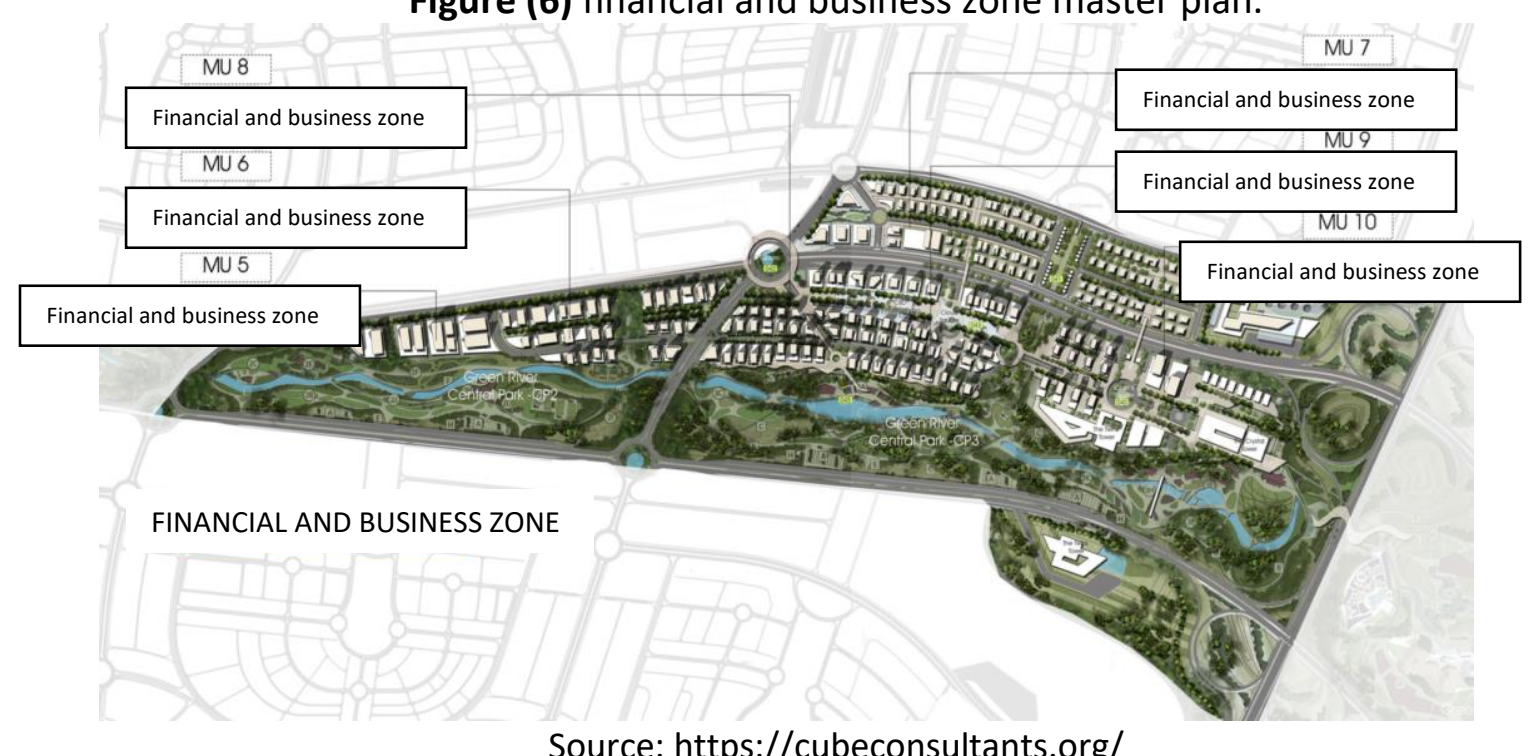

Source: https://cubeconsultants.org/

Figure (7) financial and business zone land use

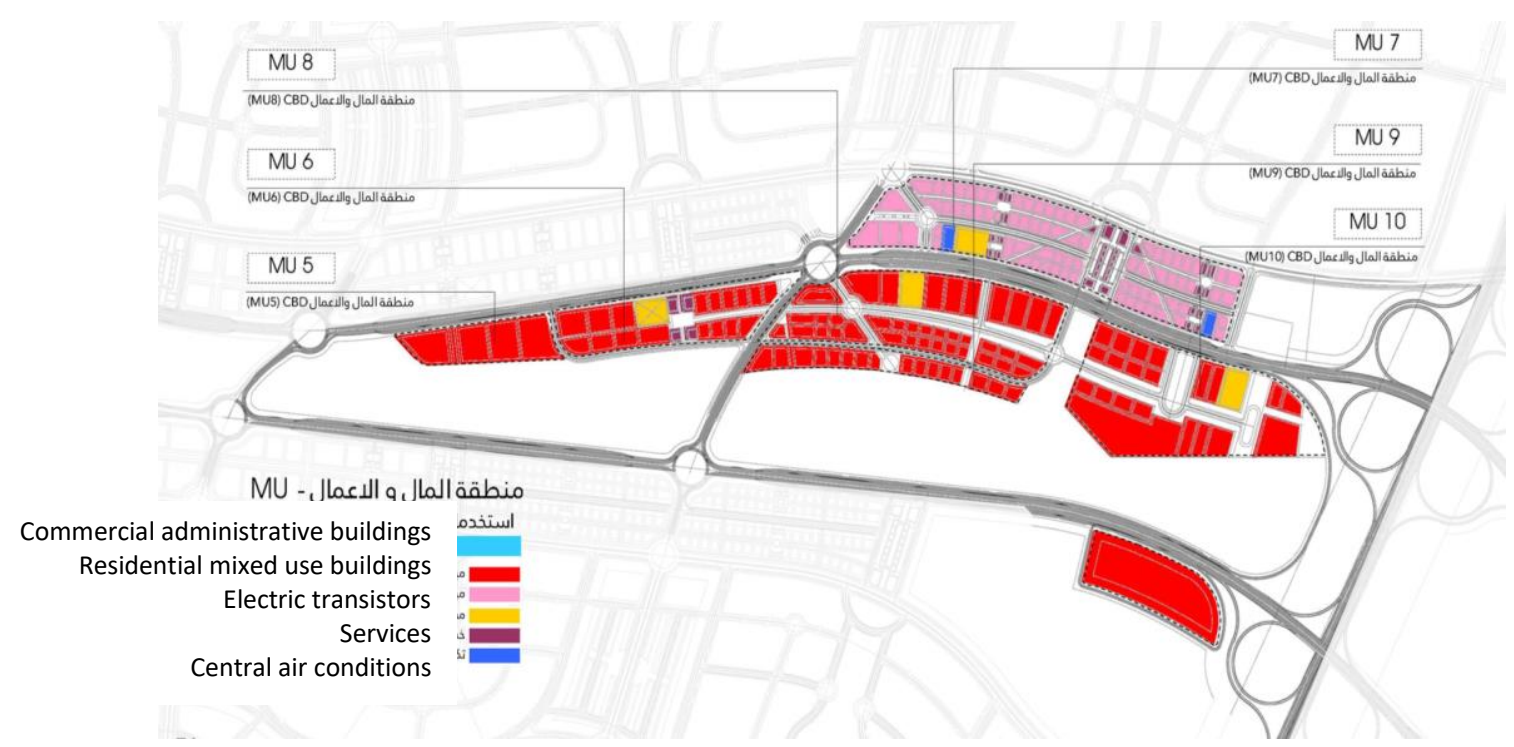

Source: https://cubeconsultants.org/

\section{Biophilic city checklist}

This paper aims to sketch out guidelines needed to shift toward biophilic cities in the Egyptian new cities by learning lessons from Singapore case study; the checklist shows the comparison between Singapore and Cairo capital to show how to apply biophilic city main elements on each scale as shown in table 6. 
Table (6) Biophilic elements check list for Singapore and the capital Cairo (wedian city) - source :researchers.

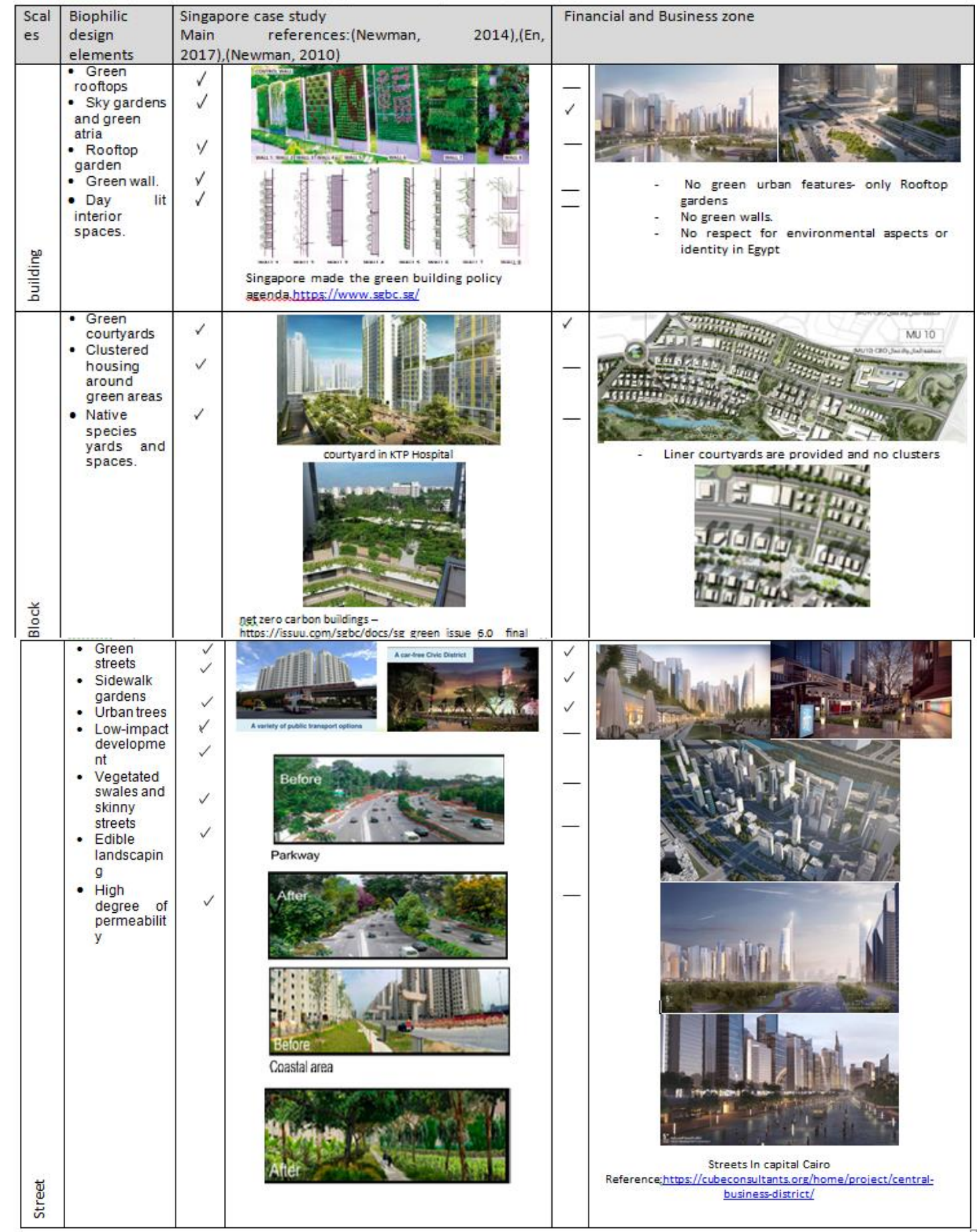




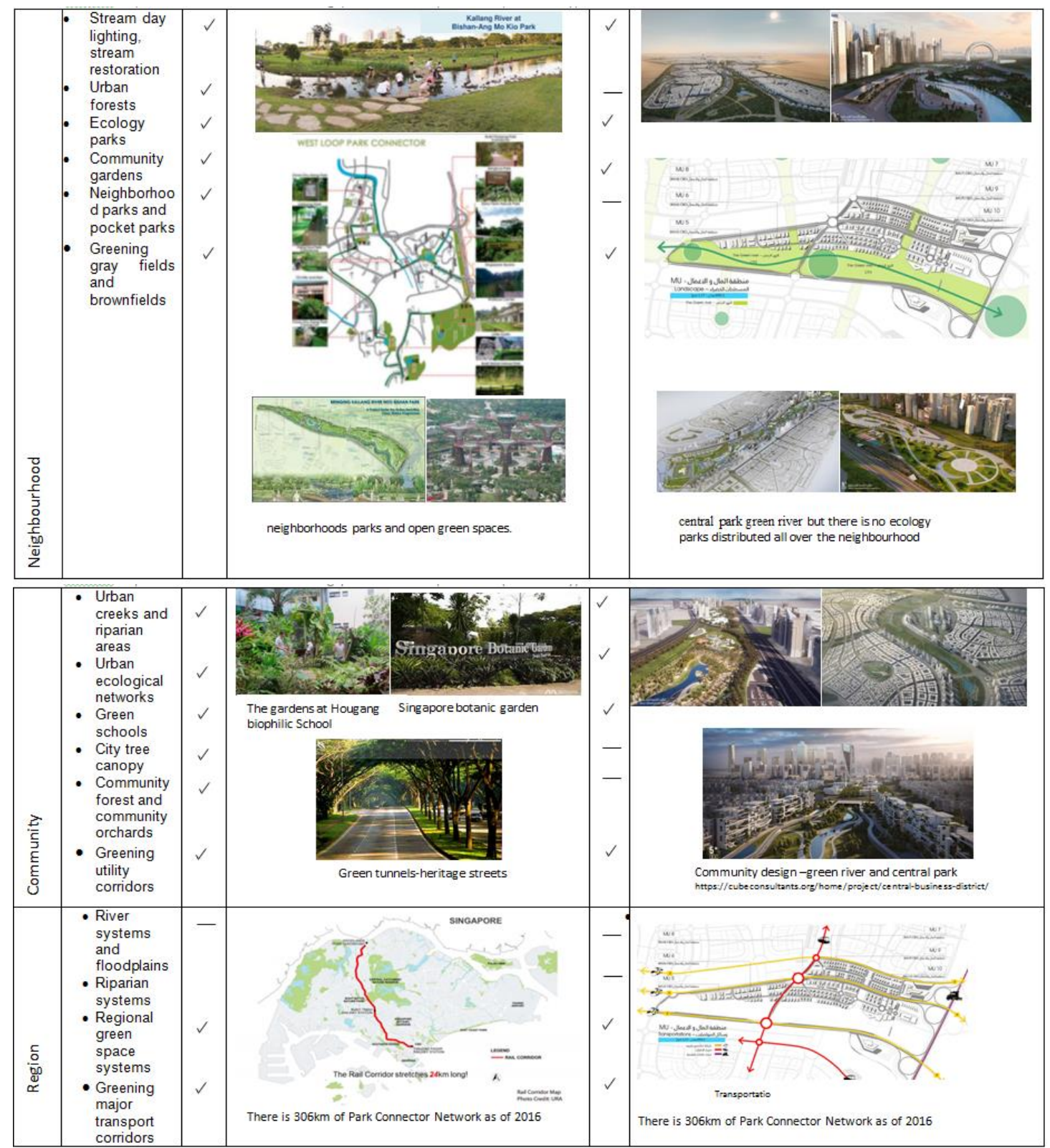

\section{Conclusion}

Evolving biophilic cities demonstrate convincingly that there are different tools and strategies to promote nature in cities. Context is significant in selecting the best strategy. There is no single approach, but just guidelines to enhance the biophilic city approach and principles.

The presence of nature imagining buildings, streets, neighbourhoods, and cities immersed in nature helps to create a positive image of places people will want to live in the future. An important step in developing biophilic approaches is to look for nature already in cities first.

Singapore, which over a number of years, has demonstrated how high density, the limitation of natural sources, and climatic change all do not have to mean reduced natural systems. It succeed in applying smart and sustainable city principles on many levels, Smart solar, lighting, irrigation, homes, car park management system and Urban Environmental Modeling.

Singapore applied the green system, it aims to provide clean air, water and land and it became a leader on green economy and developed green industry. Many 
lessons can be learned from this case study, one feature that has enabled Singapore's success is the use of a comprehensive mix of financial incentives, regulations, demonstration programs, capacity building, and consumer awareness and education.

The new Cairo capital (Wedian city) is a new smart city approach differ than any new city in the Egyptian urban context in the last decay. It was designed based on 7 principles as green, smart, sustainable, resilience city but in fact, there is a missing linkage between city principles and the suggested master plan and design as many sustainable principles did not apply. In spite that new Cairo capital is a green city -as principle- but in fact, its master plan lacks many biophilic design elements

This vision guideline offers a set of strategies to guide growth over the next 40 to 50 years. Therefore, it must be resilience enough to adjust to future changes. It calls for a new destination designed to embrace and adapt its natural desert setting in Egypt and it should reflect the Egyptian identity and environmental, contextual aspects. The next section will clarify the missing biophilic principles that should be added to increase the efficiency and the resilience of the city.

The research found some missing biophilic design elements shown in different scales as shown in table 5 .

Buildings must inform and educate about environment and desert ecology and invites a deeper awareness of and connection with this unique natural setting, not copying architecture features without the respect of the environmental aspects in Egypt. Urban design regulations must be applied on building design principles to match biophilic city aspects and measure the impact of the great area of glass on the building elevation and design. Green walls should be designed and much green roof top gardens

Blocks: Clustering building around green courtyard instead of longitudinal ones, prevent deep plot subdivision to prevent the lack of sunlight that may affect the biophilic city principles and to encourage walkability. Changing landscape to edible landscaping to be more smart and sustainable cities. Streets should provide Visual Connection with Nature.

Streets networks : new Cairo capital contains some sidewalk gardens, but creating a continuous tree canopy above all major roads is significant for biophilic cities, There is also the idea of extending of green elements in soft scape along connectors.

Neighbourhoods design: on service scale, Community parks should be added in master plan, ecology parks network should be designed and green pockets and think of green schools.

Communities: Water resources is one of the most important issues should be solved.

On regional scale, river systems and food plains and making parks connectors are needed instead of one green river.

The most successful biophilic cities are places where the public and private sectors have come together, where city agencies are communicating and collaborating, from day one, where non-profits and other groups have joined forces to raise more nature in urban environments. 
Design considerations must be applied to optimize the impacts of a presence of water as Prioritize a multi-sensory water experience to achieve the most beneficial outcome.

Urban biophilic Design Guidelines focus on the larger considerations between building forms and spaces, open space, street fabric, and the activities across them. The focus in on the relationship between the different forms, uses, inter-space connections, activities, access to, from and between buildings and spaces, streetscape and design of plazas, outdoor park space and transportation with deep understanding of the Egyptian context.

Such guidelines must also address health and safety concerns of these spaces, ensure accessibility for individuals with disabilities.

There are still many important research and policy questions to be answered in moving cities toward biophilic urbanism. Future studies should focus on the economic benefits of biophilic Cities especially in the Egyptian context and study the impact of biophilic cities on societies, and user's physiology. Much additional research is needed to better understand, moreover, the full package of resilient benefits that is provided by a biophilic cities and even the different basic ways in which urban biophilia can manifest.

\section{Research limitations}

The research has some limitations; first the new Cairo capital is still under construction so the analysis is based the initial released documents, figures and master plan not field study. Second, the biophilic cities check list is not accurate enough, it needs much studies and adding much details on each scale. But the research can be considered as a start point for the concept of biophilic cities.

\section{References}

Beatley T. (2017). Biophilic Cities and Healthy Societies Urban Planning 2017, Volume 2, Issue 4, Pages 1-4 .

Beatley, T. (2016) Biophilic Cities and Urban Resilience. In: Handbook of Biophilic City Planning and Design. Island Press, Washington, DC

Beatley, T. (2012). Green Cities of Europe, Global Lessons on Green Urbanism. Island Press, Washington, DC.USA

Beatley, T. (2010).Biophilic Cities: Integrating Nature into Urban Design and Planning; Island Press: Washington, DC, USA.

Beatley, T. (2004). Native to Nowhere: Sustaining Home and Community in a Global Age, Washington, D.C.: Island Press, $392 \mathrm{pp}$.

Beatley T., and Newman P. (2013). Biophilic Cities Are Sustainable, Resilient Cities, Sustainability, 3328-3345.

Browning, W.D., et al. (2014). 14 Patterns of Biophilic Design. New York: Terrapin Bright Green, LLC.

Cube consultants, https://cubeconsultants.org/home/cairocapital) (Accessed 20/5/2018).

Girling, C.; Ronald, K. (2005)." Skinny Streets and Green Neighborhoods: Design for Environment and Community; Island Press: Washington, DC, USA.

Griffin, C. (2004). An introduction to Biophilia and the built environment. RMI Solutions. 20(1): 7-11 
Herschong, L.; Roger, W.; Stacia, O.(2002) Day lighting impacts on human performance in schools. J. Illum. Eng. Soc. Summer 2002, 31, 101-114.

http:// www.mdpi.com/journal/sustainability

The capital Cairo web site http://thecapitalcairo.com (Accessed 2018-03-18).

Towards a sustainable and resilient Singapore. Singapore's Voluntary National Review Report to the 2018 UN High-Level Political Forum on Sustainable Development.

https://sustainabledevelopment.un.org/content/documents/19439Singapores_Volunt ary_National_Review_Report_v2.pdf

Maas J., et al.(2009). "Morbidity Is Related to a Green Living Environment," Journal of Epidemiology and Community Health 63(12): 967-973.

Newman,P. (2013) Biophilic urbanism: a case study on Singapore, Australian Planner, 51:1, 47-65, DOI: 10.1080/07293682.2013.790832

Kellert, S. (2005). Building for Life: Designing and Understanding the Human-Nature

Connection. Washington, DC: Island Press.

Kellert, Stephen R., et al , (2008). Biophilic Design: The Theory, Science and Practice of Bringing Buildings to Life. Hoboken, NJ: Wiley.

The Singapore green plan 2012, A clean environment, water for all, together a sustainable singapore,ministry of enviroment and water resources. http://unpan1.un.org/intradoc/groups/public/documents/apcity/unpan026598.pdf

Urban Development Consortium UDC 5+, http://www.udc5.com/project/wedian-newcapital-city/ (Accessed 2018-04-14)

Wilson, E. O.(1984). Biophilia, Cambridge, MA: Harvard University Press.

Documentary films about the new capital Cairo:

https://www.youtube.com/watch?time_continue=10\&v=Fjh_5yGtqJ8

https://www.youtube.com/watch?v=oikpSAs3bOo 